\title{
LA CENSURA GUBERNATIVA EN EL SIGLO XVIII
}

por

\author{
JAVIER BRAGADO LORENZO \\ CEFERINo Caro López \\ I.E.S. «Gran Capitan». Madrid
}

RESUMEN: En el siglo XVIII la censura gubernativa era un mecanismo del Estado para alcanzar. tres objetivos: asegurar el control sobre el pensamiento y la difusión de la producción intelectual, vigilar el orden público, favorecer la cultura y el buen gusto. La política borbónica en este campo era de perfecta continuidad en relación con la de los Austrias, y se caracterizaba por la voluntad de imponer la autoridad del Consejo de Castilla en los territorios de Aragón y Cataluña $y$ de intervenir en asuntos antes de dominio de la Iglesia; en este punto es importante notar que no pocos religiosos colaboraron con el Estado. Los gobernantes promulgaron una serie de leyes dirigidas a centralizar las tareas censorias en una magistratura llamada Juez de Imprentas, pero las competencias que este ministro llegó a acumular llevaron al recelo y la progresiva reducción de sus atribuciones a favor de otros magistrados locales; de ese modo, la censura se volvía menos eficaz. Tras la Revolución Francesa todas las normas de censura se endurecieron, llegando intentar imponer una barrera legal a las noticias y las obras procedentes de más allá de los Pirineos.

Palabras clave: Censura. Regalismo. Política cultural.

ABSTRACT: In the eighteenth century government censorship was an administrative mechanism for acbieving three main objectives: to control the production and diffusion of intellectual output, to keep public order, and to promote culture and good taste. In this field, the policy of the Bourbons was in perfect continuity with that of the Habsburgs. It was characterised by the aim of enforcing the authority of the Consejo de Castilla upon the territories of Aragon and Catalonia, and of intervening in matters that had previously been the province of the Church. It is notable that many clergymen collaborated with the State. The ministers enacted a series of laws aiming to centralise censorship in a single magistracy called the Juez de Imprentas, but this magistrate accumulated so much power that it led to resentment and to a progressive reduction of bis area of competence. Thus, censorship became less effective. After the French Revolution all censorship guidelines became tougher, as an attempt was made to raise a legal barrier against news and writings from beyond the Pyrenees.

Hispania, LXIV/2, núm. 217 (2004) 571-600 
KEY wORDS: Censorship. Bourbons. Spain. Eighteenth Century. Cultural Policy.

En la actualidad el término mismo es motivo de repulsa por sus connotaciones, que remiten a formas rechazadas de ejercer el poder político; sin embargo, para evitar el anacronismo histórico más elemental, habrá que recordar que la censura, en cuanto «barrière de sécurité que l'Etat dresse entre luimême et le fait passible de délit selon les normes décrétées par cette défense» era un mecanismo típico de los gobiernos del siglo XVIII ${ }^{1}$. También convendrá tener en mente que a esa normalidad de la práctica política se adherían muchos intelectuales coetáneos y que la defendían en cuanto instrumento para reformar el gusto y dirigir la educación de sus conciudadanos ${ }^{2}$.

Precisamente las normas dictadas para la defensa del estado justifican esta investigación, sobre un tema que no ha levantado en España demasiado interés $^{3}$. El marco temporal se justifica por el inicio de la nueva dinastía y por la

I LAVANDier, J.P.: Le livre au temps de Marie-Thérèse, Berna 1993, p. 39. Sierra CORELla, A.: La censura de libros y papeles en España, Madrid 1947, p. 17, tenía una opinión distinta en materia: «Sólo algún pobre escritor, contagiado, desgraciadamente, de un liberalismo trasnochado, podrá ya en lo sucesivo combatir, con apariencia de convencimiento, el ejercicio legal de la censura científica y literaria, como si esta función vital de la sociedad en general fuese una enojosa e injusta intromisión del poder, cercenadora humillante de la inteligencia».

2 Véase CARo López, C.: «Los libros que nunca fueron. El control del Consejo de Castilla sobre la imprenta en el siglo XVIII», Hispania, LXIII/1, 213, 2003, pp. 161-198. Esta autorización, que era un acto administrativo, nada tiene que ver con la usual "censura» que se incluía en los libros impresos en España junto con la Tasa en la que se fijaba su precio de venta. Tal «censura», parecer de un examinador que certificaba que el texto no contenía proposiciones prohibidas o peligrosas, con el paso del tiempo se había convertido en un ejercicio de alabanza del autor por parte de su censor, hasta llegar al punto de que en algunos casos el mismo autor buscaba un censor cuyo nombre podía añadir más fama, con sus elogios, a la obra que deseaba dar al público.

3 Investigaciones sobre la censura en España durante el Siglo de las Luces: BouZA, F.: «Para qué imprimir. De autores, público, impresores y manuscritos en el Siglo de Oro», Cuadernos de Historia Moderna, 18, 1997, pp. 31-50; CAPEL MARTíNEZ, R.M.: «Venturas y desventuras del matrimonio a los ojos de un clérigo ilustrado", Cuadernos de Historia Moderna 19, 1997, pp. 39-63, estudia la política del cordón sanitario contra la Revolución Francesa pero no ofrece indicaciones generales; DOMERGue, L.: Censure et lumières dans l'Espagne de Charles III, París 1982, es una tratado episódico que se pierde en detalles sin llegar a ser concreto. Se funda en conocimientos indirectos; ID. "Secularización y censura en tiempos de un monarca ilustrado", Carlos III y la Ilustración, Madrid 1989; ID. «El romance de cordel y la historia vista desde Valencia», El siglo que llaman ilustrado, Madrid 1996, resalta el desprecio del gobierno por los gustos populares; ID. La censure des livres en Espagne à la fin de l'Ancien Régime, Madrid 1996; EgulZabal, J.E.: Apuntes para una bistoria de la legislación sobre imprentas desde el año 1480 al presente, Madrid 1879; GÓMEZ-REINO Y CARNOTA, E.: Aproximación bistórica al derecho de la imprenta y de la prensa en España, Madrid 1977; GONZÁLEZ DE ChÁvez MENÉnDEZ, "Curas y manuscritos del Dieciocho canario», Estudios Dieciochistas, I, Oviedo 1995; A. GONZÁlEZ PALENCIA, J.: Estudio bistórico sobre la censura gubernativa, I, Madrid 1934, estudio completo aunque se resiente del paso de los años; LóPEZ VIDRIERO, M.L. «Censura civil e inte-

Hispania, LXIV/2, núm. 217 (2004) 571-600 
formación del Reglamento de 1805, en que se condensan las directrices de toda la legislación anterior en materia de censura, con tres aspectos clave: religión, buenas costumbres y regalías, aunque las razones de la censura no se limitaban a estos campos y abarcaban también el orden público. Como decía Suárez, criticando a Bonola,

gración nacional: el censor ilustrado», El mundo bispánico, II, Madrid 1996, estudio de las grandes líneas del desarrollo de la censura, pero demasiado breve; ORTEU BERROCAL, M.: «La literatura clandestina en la España de Carlos IV", Cuadernos de Historia Moderna, 17, 1996, pp. 71-104, buen análisis del proceso de colaboración de la Inquisición con el poder estatal; RUMEU DE ARMAS, A.: Historia de la censura literaria gubernativa en España, Madrid 1940, seguramente la investigación más completa en materia; SERRANO SANZ, M. «El Consejo de Castilla y la censura de libros en el siglo XVIII", Revista de la Biblioteca, Archivo y Museo de Madrid, 1906-1907; PARdo TOMÁs, J.: Ciencia europea y censura inquisitorial española (1559-1707), Valencia 1987; TOMÁs Y VALIENTE, F.: «Expedientes de censura de libros jurídicos por la Inquisición a finales del siglo XVIII y principios del XIX», Anales de Historia del Derecho Español, Madrid 1964. A pesar de su edad sigue siendo provechoso consultar SARRAIlH, J.: La España ilustrada de la segunda mitad del siglo XVIIL, Madrid 1979 (ed. original 1954). En el presente estudio se considera la práctica de la censura en cuanto actividad de producción y control de la ideología. Más que conciencia de clase, se trataría de la manifestación de una mentalidad, como dice MARAVALL, J.A.: «Espíritu burgués y principio de interés personal en la Ilustración española», Estudios de Historia del Pensamiento Español, Madrid 1991, pp. 250 y 245 : «un elemento ideológico es un factor estructural y pertenece al mundo de lo real, con la misma condición de los que llaman factores materiales». Sobre la ideología desde el punto de vista teórico y como objeto de historiografía, véase LOwE, D. Historia de la percepción burguesa, México 1986; JimÉNEZ LOZANO, J.: "La percepción castiza del ilustrado», La Ilustración en España y Alemania, Barcelona 1989; DíAZ BARRADO, M.P.: «Estructuras ideológicas, poder y sociedad en la España de Carlos III", Carlos III y su siglo, Madrid 1990. Bajo las leyes de la censura se revelan los afanes del Poder por asegurarse la transmisión de mensajes idóneos a formar una opinión pública, en el sentido de ideología cuando consiste en la manipulación de la información (ENCISO RECIO, L.M.: «Prensa y opinión pública», Historia de España, XXIX, II, Madrid 1985, pp. 197-199). El objetivo era ganarse al pueblo, ese pueblo que según Egido se había demostrado «decisivo» durante la Guerra de Sucesión y que durante la crisis institucional de los años 1758-1759 habría tomado conciencia de su derecho a estar informado (T. EGIDO, Sátiras políticas, Madrid 1973, pp. 42-52). La censura ilustrada era por lo tanto el control de la producción ideológica de los adversarios políticos y también la garantía del monopolio del mensaje propagandístico. Sobre este asunto, véanse también J. ÁlvAREZ BARRIENTOS, «La profesión del escritor ante el reformismo borbónico», El reformismo borbónico, Madrid 1996; ANES, G.: «La Inquisición en la Encyclopédie», El siglo que llaman ilustrado, Madrid 1996; DOMERGUE, «Secularización...» cit; ID. La censure... cit; EGIDO, T.: Prensa clandestina española del siglo XVIII. «El Duende Crítico», Valladolid 1968; ID. Opinión pública y oposición al poder en la España del siglo XVIII, Valladolid 1971; ID. "La oposición y el poder», Carlos III y la Ilustración, I, Madrid 1988; GonZÁlez De Chávez, op. cit; A. GonZÁlez PAlenCIA, El sevillano don Juan Curiel Juez de Imprentas, Sevilla 1945; LARRIBA, E.: «Inquisidores lectores de prensa ilustrada», El mundo bispánico cit; LÓPEZ-VIDRIERO, M.L.: «Censura civil e integración nacional» El mundo bispánico, cit. vol. II; MÁs GalváN, C.: «Una versión española del Sínodo de Pistoia», Iglesia, sociedad y Estado, Alicante 1991. Las leyes: Novísima Recopilación de las Leyes de España, dividida en XII libros, mandada formar por el señor don Carlos IV, Madrid 1805 (en adelante, NoR). La legislación de imprenta se encuentra en los títulos XV, XVI, XVII e XVIII del libro VIII. GómEZ-REINO Y CARNOTA, op. cit. p. 19 , y comentario pp. ss. 
¿Es medio juicioso y oportuno publicar un libelo en forma de fábula capaz de incendiar los espíritus más apagados y modestos, y de ulcerar las más sanas consciencias? ¿Le parece a V.M. que está el mundo civil poco revuelto, que quiere enredar también el mundo religioso con escandalosas revoluciones? ${ }^{4}$.

En lo político Forner, en su Apología, argumentaba que así como en la sociedad civil «se prohíben santísimamente las acciones que desbaratan el nudo de la seguridad pública, ¿por qué en la república literaria no se prohibirán con igual calificación las doctrinas en que [...] se atropellan los principios más sagrados de la religión y de la sociedad?». En el campo literario, además de salvar la sociedad, se trataba de orientar los gustos y la cultura del público en vistas de un fin de mejora cultural y moral del país. Calvijo y Fajardo, en el Pensador, siguiendo las ideas de Luzán, sostenía la necesidad de la censura literaria para que se prohibieran los textos no coincidentes con los cánones del buen gusto; esa misma teoría la repetiría Urquijo en el prólogo a su traducción de la Muerte de César de Voltaire en $1791^{5}$. «Es peculiar Instituto del Censor de una obra examinar si es o no útil al Público", declaraban Juan Pérez Villamil y Joseph Ferrer al aceptar la censura de la obra Diseño de derecho público en $1784^{6}$.

Marcando una continuidad sustancial con la política de los Austrias, desde principios del siglo XVIII la nueva dinastía había reiterado la prohibición de imprimir sin licencia previa del Consejo de Castilla ${ }^{7}$. Antes de la publicación había que presentar el manuscrito a la censura, pero en sus orígenes esa medida se había tomado en consideración a los derechos de las personas eventualmente lesas y no a la defensa de la religión o del orden público, para justificarla ${ }^{8}$. La Escribanía de Gobierno era entonces el único tribunal competente para conceder las licencias de impresión, pero en temas de Estado la Real Orden 28/IX/1744 establecía que el permiso debía solicitarse directamente al rey, que de esta manera se colocaba fuera y por encima del imperio de la ley. Sea como fuere, parecería que el mecanismo censorio fuera omnipotente, pero también es cierto que los órganos censorios puestos en función por el poder estatal no eran

4 SuÁrez de Molina, Páxaro en la Liga, 1798, pp. 30-31.

5 Citados en ALBORG, J.L.: Historià de la literatura española, III, Madrid 1980 pp. 691, 247-248.

6 29/VIII/1784, Archivo Histórico Nacional, Consejos, legajo (en adelante, AHN Cons leg) $5547 / 78$.

7 Real Resolución (el adelante, RR. Otras abreviaturas: RC, Real Cédula; RD, Real Decreto; RO, Real Orden; RP, Real Provisión; NR, Nueva Recopilación) 30/VI/1705, en NoR, I, VII Auto 22, y VIII, XVI, 11, reiterada en RO 4/X/1728 Mandando no se permita la impresión de papeles relaciones $n i$ otra cosa alguna y que se notifique a los impresores, dada por el rey mediante el Gobernador del Consejo; RD 6/XII/1749 NoR VIII, XVI, 8. El hecho de que esas disposiciones se reiteraran en tantas ocasiones indica no sólo que no se cumplían, sino también la importancia que el gobierno atribuía al control de la imprenta. ORTEU BERROCAL, op. cit. se interesa por la represión de los impresos clandestinos, y recuerda que si en tiempos de Carlos III el Consejo de Castilla fue el primer impulsor de las reformas, bajo Carlos IV se convirtió en el principal defensor del Antiguo Régimen (pp. 76 ss.).

8 Auto del Consejo de 20/IX/1712, NoR VIII, XVI, 12.

Hispania, LXIV/2, núm. 217 (2004) 571-600 
independientes, que las censuras del Consejo de Castilla iban más allá del alcance de los ministros, y que éstos presionaban a los jueces de imprentas o prohibían las publicaciones que no les agradaban por medio de Reales Órdenes. A principios del Setecientos, como indica Rumeu de Armas, no existía independencia efectiva del Juzgado de Imprentas, porque, "cuando la censura se encomendó a los jueces, los Secretarios, desde sus despachos, prohibían cuantas publicaciones deseaban de Real Orden ${ }^{9}$. Además, la licencia estatal no era garantía definitiva, porque la Inquisición podía intervenir en cualquier momento para prohibir cualquier impreso.

El mismo dispositivo de control de la imprenta que en Castilla se mandó aplicar en la Corona de Aragón, porque allí se estaban imprimiendo y reimprimiendo libros sin licencia, por la Real Cédula de 17 de diciembre de 1716 por la que se imponía en el reino la censura previa del Consejo de Castilla ${ }^{10}$. El control central se pone de manifiesto cuando en 1722 se concedía la subdelegación de la Comisión de Impresiones a don Joseph de Camargo oidor en la Audiencia de Zaragoza para hacerlo responsable de la censura de imprenta en Aragón, con lo que se lo convertía en vicario de las atribuciones del poder central.

En 1756 el Consejo se ocupó también de reiterar su competencia sobre asuntos de imprenta en el Reino de Valencia, indicio seguro de que por sus puertos se realizaba un comercio que parecía peligroso a los ojos del Poder. Un Auto trataba de las competencias jurisdiccionales sobre censuras en la Corona de Valencia y Aragón y otorgaba autoridad a la Audiencia Real de conceder licencias

a excepción de la Ympresión o Reimpresión de Libros que se ha de acudir al Consejo por las Lizencias por lo respectivo a los papeles u otras cosas sueltas que se quisieren imprimir en este Reyno, se deven pedir y conseder aquéllas por esta Audiencia y por la misma nombrarse persona para la corrección assí de los Libros que se imprimieren, y se reimprimieren como de las demás cosas y papeles ${ }^{11}$.

Volviendo a las leyes sobre censura, hasta mediados del siglo XVIII no se legisló con carácter general a propósito de asuntos de imprentas, exceptuando dos medidas puntuales tomadas en 1748 y 1749 en relación con manifiestos y defensas legales porque era demasiado corriente imprimir alegaciones en pleitos con el fin de denigrar a la parte contraria. Para remediarlo no se podría imprimir «Papel alguno, de volumen grande, o pequeño sin que primero se presente manuscrito al Consejo o Tribunal en que esté pendiente el Negocio de que trate». Este asunto era extremamente importante porque la gran copia de

\footnotetext{
9 RUMEU De ARMAS, op. cit. p. 56.

AHN Cons leg 50627.

11 Consistía prácticamente en el traslado de la Instrucción Curiel - que se verá más abajo- al ámbito de la Corona de Aragón y Valencia. Auto de la Audiencia 15/XI/1756 remitiéndose a los Autos Acordados 27 y 28/XI/1716, NR I, VII, 26 e 27, ya explicados con RR 27/VII/1754. AHN Cons leg 50689.
}

Hispania, LXIV/2, núm. 217 (2004) 571-600 
papeles amenazaba con colapsar la administración de la justicia, como temía Wall cuando presentaba la Real Orden de 4 de mayo de 1760 para limitar la impresión de esos documentos dirigidos a su majestad:

El Consejo o Juez de Ymprentas, quando hayan de conceder Licencia para imprimir algún memorial, o representación a SM en materia que no pertenezca de manera alguna a las de Estado, sea con la cohartación de no tirar más que aquel, o aquellos ejemplares, que se destinen y hayan de pasar a las Rs. Manos, y que si las Partes deseasen mayor extensión de licencia, se les remita a SM por la vía reservada ${ }^{12}$.

Sin embargo, a pesar de los afanes del Poder, en toda la Península los abusos en asuntos de impresiones de libros y papeles seguían ocurriendo a despecho de las leyes ya existentes. Por esa razón se llegó a la Real Cédula de 1738 que instituía el cargo de Juez Privativo de Impresiones con jurisdicción sobre cualquier otro tribunal laico. El primer Juez fue don Juan José de Mutiloa, y como la figura del Juez de Imprentas es una pieza clave en el dispositivo legal de la censura gubernativa convendrá detenerse en sus aspectos más sobresalientes antes de continuar esta exposición.

En tiempos de Felipe II el Juez de Imprentas era la persona en quien el Consejo delegaba las funciones de control y revisión de los libros heréticos o peligrosos, nombramiento más tarde mantenido por Felipe IV en 1647, y en 19 de agosto de 1692 se lo denominaba Ministro Superintendente General de Imprentas ${ }^{13}$. A su vez este magistrado tenía facultad de nombrar subdelegados «en las Ciudades y Provincias que tubiéredes por conbeniente» ${ }^{14}$. En 1785, visto que el trabajo era tanto, se nombraron Subdelegados de Imprentas del Reino a los presidentes de las Chancillerías, Audiencias, Justicias y Corregidores (en Novísima Recopilación, VIII, XVI, 33) y veinte años más tarde se decidía la centralización de todas las competencias en un Juez de Imprentas con inhibición de todos los otros Consejos y Tribunales, para mejorar la eficacia de la censura, hasta que la Real Orden de 27 de marzo de 1808 destituía a este nuevo magistrado, Juan Antonio Melón, y mandaba encargarse de sus funciones al Consejo Real ${ }^{15}$. Tal vez la causa de esta medida que venía a deshacer lo que se

12 RD 18/XII/1748, AHN Cons leg 50692, nuevamente afirmada con RR 6/XII/1749, AHN Cons leg 11275/13 y oficio de Ensenada a José Carvajal y Lancaster, Gobernador del Consejo de Castilla; RO 4/V/1760, AHN Cons leg 50692.

13 Para una rápida síntesis de la historia del Juez de Imprentas, véanse GómeZ-REINo y RUMEU De ARMAS. Desde los años 1660 se pueden encontrar los rastros se la actividad de concesión de licencias de impresión y de control de los libreros e impresores en los registros del Patronato de Castilla (AHN Cons leg 50627) con atención especial a la Corona de Aragón como se pone de manifiesto en los primeros años del Dieciocho. Véase también GUINARD, P.J.: La presse espagnole de 1737 à 1791: formation et signification d'un genre, París 1973.

14 AHN Cons leg 50628.

15 NoR, VIII, XVI, 41, 1785; GÓMEZ-REINO, op. cit. p. 29

Hispania, LXIV/2, núm. 217 (2004) 571-600 
había emprendido pocos años atrás era la importancia y autonomía que iba adquiriendo ese magistrado, pues como dice Lucienne Domergue, «nos documents indiquent un fort pourcentage de dossiers déja adressés au Juez»» ${ }^{16}$.

Rumeu de Armas hace notar que hacia 1740 el ejercicio de la censura gubernativa pasó del Juez de Imprentas al Portero del Consejo, que era el intermediario natural entre editor y Juez, lo que daba pie a abusos fácilmente imaginables, abusos que se quisieron desterrar con el nombramiento de Curiel en 1752. Don Juan Curiel, «tradicionalista y reaccionario, contrario a las Luces, a Wall y a Campomanes ${ }^{17}$, magistrado de fuerte personalidad política, fue el eslabón más significativo en los engranajes de la censura gubernativa del Setecientos, al menos en su primera mitad. Emanó los Capítulos para impresores mercaderes y tratantes de libros, al poco tiempo de entrar en el cargo, el 22 de noviembre. Eran estos Capítulos las disposiciones técnicas que habían de respetar impresores y mercaderes de libros, con tintes fuertemente restrictivos de la libertad de acción de los profesionales de la imprenta, y de hecho éstos reaccionaron inmediatamente con el Memorial de los mercaderes... dirigido al Consejo, pidiendo su amparo ante las pretensiones del Juez de Imprentas. Pero en su Parecer los fiscales del Consejo criticaton duramente el Memorial; encontraban que el Auto de Curiel respetaba las leyes vigentes y en lugar de escuchar las quejas de los libreros proponían se investigara a los autores del documento para castigarlos «a proporción del exceso de su livertad» pues se habían atrevido a criticar al Juez de Imprentas y a usar expresiones poco respetuosas. De hecho entre otras cosas los libreros pedían la supresión del cargo de Corrector de Imprentas y «la mutación de Vro. Juez actual, que ha manifestado su encono contra los suplicantes en las causas que ha movido» ${ }^{18}$.

Los Capitulos de Curiel se articulaban en una serie de puntos para establecer una normativa censoria. El Juez de Imprentas se lamentaba de que las medidas de vigentes

16 Analizando el libro 2715, II, del AHN sección Consejos. Se trata de un registro de peticiones de licencia de impresión dirigidas al Consejo de Castilla y al Juez de Imprentas, con los siguientes resultados: en 1802 hubo 35 peticiones al Juez contra 29 al Consejo, en 1803 fueron 95 contra 40, en 1804 el juez recibió 124 y el Consejo 49. Domergue, Censure des livres cit. p. 337.

17 GómeZ-Reino, op. cit. p. 40.

18 Capítulos para impresores mercaderes y tratantes de libros por Juan Curiel de 22/XI/1752, AHN Cons leg 50693. Domergue, Censure... cit. califica el Auto Curiel de «durcisssemente de la politique de censure» y hace notar que con estas medidas se pone en evidencia que «le régalisme coïncide politiquement avec «despotisme éclairé» (p. 31). Los libreros, según la misma autora, vieron en ese Auto «una declaración de guerra». «L'Auto curiel fut considéré par les marchands de livres comme une déclaration de guerre» (pp. 20 ss.). Parecer de los Fiscales de 28/I/1753, AHN Cons leg 50650. En el mismo está el Memorial de los mercaderes... 1752. RR 27/VII/1754, NoR VIII, XVI, 22. Todo el expediente en AHN Cons leg 50693. CORONAS GONZÁLEZ, S.M.: El libro de las leyes del siglo XVIII, Madrid 1996 p. 837. 
se hallan sin puntual observación [...] lo que ha dado motivo a que algunos Impresores, y Tratantes en Libros, o se crean dispensados por la impunidad de otros delinquentes, o disculpados por la ignorancia de las leyes, que deben saber, o por estimarlas abolidas por su inobservancia, o contrario uso.

Y deseaba corregir la situación. El punto primero estipulaba que no se pudiera imprimir nada «aunque de pocos renglones» sin licencia del Consejo o del Juez de Imprentas, lo que no era una novedad, pero sí lo era la pena, de seis años de destierro y 2.000 ducados de multa (NR I, VII, 22, 23, 33, y Auto 19). Tampoco era novedoso que las reimpresiones tuvieran que recibir la licencia del Consejo (punto $2^{\circ}, N R$ I, VII, 33 e II, IV, 48), pero ahora se perfeccionaba el sistema de control porque los impresos no podrían distribuirse en el mercado si primero no se veían y tasaban por el Corrector General, en una medida tomada con toda evidencia para evitar que se modificaran los textos una vez recibida la licencia de impresión (NR I, VII, 23, 24). En cada libro debería aparecer la licencia, la tasa, el eventual privilegio y los datos del autor y del impresor, (NR I, VII, 2, 33). El punto quinto ponía de manifiesto la severidad del Juez ante casos de «doctrina de sagrada escritura y de cosas concernientes a la Religión de nuestra Santa Fe Cathólica» que no tuviesen la licencia del Consejo o estuviesen en el Índice de la Inquisición, porque habría que quemar los tales libros y ejecutar a sus responsables (NR I, VII, 24). Siguiendo cuanto establecido en el Real Decreto de 1749, no se podían imprimir sin licencia las «informaciones en derecho, manifiestos, y defensas legales» porque su naturaleza misma llevaba a usar expresiones poco acordes con la paz y los buenos modales ${ }^{19}$. El articulado de Curiel imponía a continuación a los impresores la obligación de franquear siempre sus puertas a los funcionarios encargados de hacer registros y pesquisas en los talleres (NR I, VII, Auto Acordado 26, punto $\left.7^{\circ}\right)$. El punto siguiente declaraba que la tasa debía indicar el precio del libro (NR, VII, Auto 6).

Curiel seguía imponiendo el respeto de la ley 12 de la Recopilación (I, Título X) sobre impresión de documentos papales, en el punto 9; el 10 se refería a la reimpresión de «Cartillas, Flos Sanctorum, Constituciones Synodales, Artes de Grammática, Vocabularios, y otros Libros de Latinidad no siendo Obras nuevas» que se podían dar a la imprenta sin nueva licencia, «sin embargo no se reimpriman sin Licencia de los Prelados, y Ordinarios en sus Distritos, y Diócesis», (NR I, VII, 24 cap. 4) y lo mismo valía para las «Licencias que diesse el Señor Inquisidor General, y los del Consejo de la Santa, y General Inquisición, por lo perteneciente a las cosas tocantes al Santo Oficio, y las que diere el Señor Comissario General de la Santa Cruzada por lo tocante a Bulas, y demás Cosas

19 RD 12/XII/1749. NR I, VII, Auto Acordado 17. «Les autorités borboniques se sont vite avisées que le danger venait surtout des imprimés brefs (ceux qu'elles désignent sous le terme de papeles)». En 1749 se estigmatizan los «manifestes, défenses légales et autres, comme renfermant trop souvent satires et propos blessants». DOMERGUE, Censure et lumières cit. p. 25. 
pertenecientes a aquel Consejo, poniéndolas al principio del Libro", (NR I, VII, 24 cap. $4 ; 12$, punto 11 ). Se puede notar cómo, hacia mediados del siglo Dieciocho, la voluntad del gobierno en asuntos de censura y control ideológico iba encaminada a evitar cualquier roce con el Santo Oficio, o al menos esa era la postura del Juez de Imprentas. Las impresiones debían realizarse en «Papel fino semejante al de las Fábricas de Capellada y de ningún modo en Papel ordinario, que comúnmente se llama de Imprenta», según el punto 12 (RO 5/VI/1758); Luego venían las disposiciones sobre importación de libros extranjeros, que desde el último cuarto del Setecientos sería una de las máximas preocupaciones de los gobernantes: el punto 13 prohibía importar libros escritos en romance impresos en el extranjero sin especial licencia del rey. La pena para los transgresores era la muerte, lo que demuestra la preocupación por la importación y circulación de obras no sólo extranjeras - ya de por sí sospechosas - sino además en español, lo que las hacía potencialmente peligrosas al ponerlas al alcance de un público más amplio (NR I, VII, 24 cap. 1 y Auto 8). El control de los libros extranjeros se perfeccionaba pues no se podían vender si el Consejo no los había tasado primero (punto 14, NR I, VII, 29 y Auto 8) pero además no se podían vender sin especial licencia los libros «escritos por Estrangeros de primera Impresión, y por Naturales de segunda fuera del reyno", (NR I, VII, 23, 24, Auto 8, punto 15). Ningún librero, mercader o impresor debía de ninguna manera estorbar el trabajo del Juez de Imprentas, sino que había de colaborar con esa autoridad (punto 16, NR I, VII, 24 cap. 6 Auto 2). Las normas que se dictaban tenían evidente función de control y vigilancia pero algunas, como la del punto 17, llevaban el celo hasta límites insospechados, pues establecían que no se podía hacer almoneda en bloque de una biblioteca hasta pasados 50 días de la defunción de su propietario (NR I, VII, Auto 28); aunque no se decía, resulta claro que era para que el Juez de Imprentas pudiera repetir la hazaña del cura y del barbero cervantinos. El punto 18 seguía con el control de la difusión de los libros extranjeros, prohibiendo reimprimir, importar, o vender, «missales, diurnales, pontificales, manuales, breviarios en latín, ni en romance, ni algún otro libro de coro, impresso fuera de estos Reynos, aunque lo estén en el de Navarra» sin especial licencia del rey. Prohibición perpetua «para que en ellos [libros] no pueda haver ningún vicio contra lo ordenado por su Santidad», (NR I, VII, 27). Es de notar la amplia discrecionalidad reservada a la voluntad de la Corona por encima y al margen de las leyes que ella misma alentaba o emanaba directamente. El punto 19 declaraba que las normas precedentes debían aplicarse a las Coronas de Castilla y de Aragón, (NR I, VII, Autos 26 y 27) 20.

Ya se ha dicho que el reglamento propouesto por Curiel recibió inmediata crítica por parte de los libreros de Madrid. Éstos argumentaban que como se lo había nombrado Juez Privativo, ahora Curiel quería demostrar su poder con un Auto

20 Nótese que las referencias al articulado de la Nueva Recopilación son añadidos al margen posteriores a la redacción del documento original. 
en que se introducen muchas novedades perjudiciales [...] se renuevan y resucitan Leyes olvidadas, y derogadas con el uso contrario, y costumbre legítimamente prescripta con positiva noticia y tolerancia de Vros. Reales Ministros y Antecesores en su Comisión [de Imprentas].

Penas que los libreros consideraban severísimas, desproporcionadas a las culpas, y predecían la ruina de los negocios editoriales, pues nadie tendría valor de arrostrar una edición, no porque las nuevas normas técnicas fueran demasiado complejas, sino «especialmente por el temor de las penas gravísimas que se imponen a los transgresores del decreto»; por el contrario, los libreros presentaban una colección de medidas que les eran favorables, y que los reyes habían sancionado desde Toledo 1480, y criticaban y rechazaban los 19 capítulos del Auto con razonamientos para rebatir las propuestas administrativas del Juez de Imprentas. Al punto tercero, sobre Corrector general, «Pues es público y notorio que el Corrector no lee libro alguno, ni hace más que poner las erratas, que le da el mismo Autor con la fee de que salbada corresponde a su original»; a propósito de la tasa, porque según los libreros «Se reduce a un formulario de la Secretaría de Govierno, que en el día de hoy no sirve de regla, porque los Libros que se encuentran venales, se compran, y venden por mucho menos de la Tassa». Al punto cuarto, porque era imposible saber con seguridad el nombre verdadero del autor, lo que no deja de ser curioso, como poco. También criticaban, y mucho, el punto quinto, protestando por las duras penas impuestas por tenencia de libros prohibidos por la Inquisición en asuntos de fe. Esta postura es bastante desconcertante porque parece querer reducir la importancia de los asuntos de religión y tal vez sea la manifestación de un incipiente sentimiento laico en la producción intelectual. La justificación de una proposición tan atrevida era que

Y hay muchos vasallos de V.M. que no saben ni pueden saver qué Libros son los prohibidos ni han visto expurgatorios en su vida y si tienen algún libro vedado en su poder, será porque lo heredaron, o por otra causa inculpable.

En los puntos 10 y 11 , sobre reimpresiones, acusaban a Curiel de querer usurpar competencias que eran tradicionales del Consejo; el punto 12 de los libreros era muy significativo: en él se proponía que se hiciese en todo como era corriente en Francia, y que el Juez de Imprentas se dejara asesorar por impresores o libreros peritos en materia de calidad y tipos de papel; el punto trece decía que Curiel se refería a una ley caída en desuso y que ocasionaría graves perjuicios porque los libros de "Derecho civil, y Canónico, Theología moral, y expositiva, Medicina y otras facultades, se han impreso siempre fuera del Reyno", lo que más que una disculpa era un comentario bien triste para la cultura española. Los libreros, en cuanto empresarios, también denunciaban la competencia desleal del monasterio de El Escorial, que en virtud de sus privilegios no hacía que sus libros se tasaran por el representante de la autoridad civil sino 
por el Comisario General de Cruzada (punto 18). Como ya se ha dicho, el memorial de los libreros no obtuvo ninguna respuesta positiva del Consejo de Castilla y se ratificó de todo punto lo establecido por el Juez de Imprentas ${ }^{21}$.

A raíz de la Instrucción de Juan Curiel de 19/VII/1756 y las protestas que causó se emanó el Auto del Consejo de 21/VII/1756 con la decisión final de los fiscales de aceptar las medidas que proponía. Tocaba las normas que habían de seguirse para presentar las peticiones de licencia de impresión, en las que el Portero entregaba la obra al censor designado y éste debía mirar

No sólo sobre si contienen algo contra la Religión, las buenas costumbres, o contra las Regalías de su Magestad, sino también si son apócrifas, supersticiossas, reprobadas o cosas vanas, y sin provecho, o si contienen alguna ofenssa a Comunidad, o a Particular, o en agravio al honor, y decoro de la Nación.

El nombre del censor había de quedar en secreto para el autor censurado, y los libros ya impresos y que se querían vender en el reino, si hubieren sido prohibidos por la Inquisición, no se debían siquiera tomar en consideración. También se especificaban las materias excluidas de la jurisdicción de los censores, a saber asuntos de Estado, tratados de paz, la Inmaculada Concepción, asuntos de Indias o de otros Consejos, "Comercios, Fábricas, u otras Maniobras, o perteneciente a Metales, sus valores, y pesos para su comercio; o a Regalías de la Corona».

Las normas del Juez Curiel representan por tanto la postura oficial del gobierno sobre asuntos de censura en la primera mitad del siglo XVIII y son las normas que marcarían la pauta de la actitud futura, bien para confirmarlas o para modificarlas según la coyuntura política y social de cada momento. Las convicciones de Curiel se ponían de manifiesto cuando el Juez repetía sus advertencias contra

el empeño, y sagacidad con que los enemigos de la Religión esfuerzan su malicia, introduciendo cautelossamente dissmulado el veneno, y contagio de las heregías, y errores, nunca más temibles, que en los tiempos presentes, ni más dignas del cuidado y vigilancia del Consejo ${ }^{22}$.

Es decir, que entendía la tarea de censor como una lucha dirigida principalmente contra las desviaciones de la ortodoxia religiosa, y no - como sería la pauta en la segunda mitad del siglo- como empeño de mejora cultural y social. Coherentemente con sus inquietudes, Curiel daba orden de nombrar a cuarenta individuos de reconocida solvencia cultural para que ejercieran las

21 Recopilación de las leyes [...] que manda su Magestad observar a los Impressores, mercaderes, y Tratantes de Libros de esta Corte, y demás ciudades, Villas, y Lugares de estos Reynos, Real Decreto 12/VIII/1754, AHN Cons leg 11275/25 y para Barcelona 20/IX/1754 Cons leg 50689.

22 19/VII/1756, AHN Cons leg 11275/23-2. 
funciones de censores del Consejo de Castilla y gracias a las listas de elegidos se puede calibrar la dirección que estaba tomando la censura gubernativa desde los últimos años del reinado de Fernando VI hasta treinta años después.

Los elencos ponen de manifiesto el peso de los eclesiásticos en las tareas de censura, pues bien pocos de los censores eran laicos. Confrontando el primero con los de 1766 y 1789, se puede ver que no se trató de una concesión a la necesidad del primer momento, sino que la censura se alimentó de funcionarios religiosos que se pusieron gustosos - puesto que no era obligatorio ejercer esas tareas- al servicio del poder civil. Lo que queda por determinar es si se trataba de una cesión de autoridad a los religiosos por parte del Consejo de Castilla, de una colaboración consciente de los eclesiásticos que se identificaban con los intereses de la Corona, o de un recurso obligado por parte del gobierno al no poder disponer de otros colaboradores. No es una cuestión baladí porque desde los años sesenta del Setecientos la política del Consejo en asuntos de derecho eclesiástico del Estado estuvo notablemente orientada en sentido antirreligioso o cuanto poco contrario a los intereses de los regulares y las jerarquías eclesiásticas; el hecho de que tantos hombres de Iglesia optaran por colaborar activamente con el gobierno ilustrado representa una confirmación más del apoyo que los ministros reformistas encontraban entre las capas más cultas de los eclesiásticos.

A partir de ese momento, una vez aprobado el reglamento Curiel, se normalizaba el iter burocrático para la impresión de un libro: la obra se presentaba al Juez de Imprentas y éste le designaba un censor entre los cuarenta posibles. El trabajo que correspondía a estos censores, quienes además debían manifestar públicamente su parecer, consistía en

El examen de estas Obras, y su censura, [que] no sólo ha de ser sobre si contienen algo contra la Religión, contra las buenas costumbres o contra las Regalías de Su Magestad, sino también si son apócrifas, supersticiosas, reprobadas, o de cosas vanas, y sin provecho o si contienen alguna ofensa a Comunidad o a Particular o en agravio del honor y decoro de la Nación ${ }^{23}$.

En el asunto de los libreros Curiel había tenido el respaldo sin reservas de los fiscales del Consejo de Castilla, probablemente sobre todo porque los mercaderes habían cometido el error de redactar su petición en un tono demasiado beligerante; pero el Juez de Imprentas tenía un adversario más poderoso, en la figura del Secretario de Estado y del Despacho Ricardo Wall, con quien surgió

23 NR I, VII, 23 y 33, Auto Consejo 21/VII/1756, Biblioteca Nacional, Madrid (en adelante, BNM) mss. 13303, ff. 3 ss; Instrucción que de orden del Consejo, y con su aprobación ha formado el señor don Juan Curiel [...] sobre el modo, y méthodo, con que los Censores, que tiene nombrados, y nombrasse en adelante el Consejo, deberán examinar, y dar su Censura en los Libros, y Obras, que se les remitiessen, AHN Cons leg 11275/23-2 y leg 50691. Para 1766: Noticia de las Personas nombradas por el Consejo para la censura de libros, AHN Cons leg 11872/15. Para 1789: AHN Cons leg 5554/94 y AHN Cons leg 11275/23-1.

Hispania, LXIV/2, núm. 217 (2004) 571-600 
un conflicto a propósito de la censura de materias de estado que se debían ver en el Consejo, como estaba previsto por las leyes. Wall actuaba contra Curiel mediante un protegido suyo, Francisco Manuel Mena, quien había presentado un Memorial a raíz del cual se abolió la Tasa de los libros con Real resolución de 1762 , lo que representaba el triunfo de los libreros derrotados seis años antes. Es la provisión que a primera vista tendía sencillamente a liberalizar el precio de los libros, con la abolición de la tasa de precio fijo y favorecer a la industria editorial ${ }^{24}$.

Tras la primera derrota del Juez de Imprentas los libreros se sentían más seguros en sus exigencias y al año siguiente se dirigían al Consejo atacando directamente a los censores encargados por Curiel de revisar los libros y papeles.

Este expediente sería el principio del fin de la carrera de Curiel como Juez de Imprentas pues no sólo tuvo por resultado la destitución del Corrector General de Imprentas y del Portero del Consejo destinado a la Comisión de Imprentas, hombres de Curiel, a causa de sus irregularidades en la tramitación de las peticiones de licencias, sino que Campomanes rechazaba duramente las alegaciones que Curiel presentó a esas medidas, animado por el impulso soberano, pues Wall estaba transmitiendo al Consejo la real voluntad ${ }^{25}$.

El mismo Wall se había encargado también de redactar la Reprensión del Consejo al Juez de Imprentas a propósito de la licencia que se había dado a Francisco Valdemoros para su Piscator Complutense, de 23 de febrero de 1756, en la que se acusaba al Juez de Imprentas de poco celo en sus funciones e incumplimiento del deber $^{26}$. Wall se prestaba gustoso a transmitir a Curiel el desagrado de Su Majestad:

Son tales, y tantas las suciedades, insolencias y desacatos que contiene que, apenas se encontrará en él cláusula que no sea soez, obscena y desvergonzada.

El rey no sabía si indignarse - proseguía Wall- por el atrevimiento del autor o escandalizarse por la «la disimulación de los aprobantes», o asombrarse de que el Consejo - léase Curiel-_ autorizara semejantes torpezas. Y, para los

${ }_{24}$ La Real Orden es de 14/IX/1762; la abolición de la tasa se reiteró con Real Orden de 14/VI/1778. Domergue, Censure... cit. p. 21, hace notar que la abolición de la tasa no significaba también abolición de la censura previa, pero eso es evidente. Otro episodio del enfrentamiento entre el ministro y el Juez de Imprentas se había dado en el caso de la Oración fúnebre de los señores Fernando VI y María de Portugal... 1760. Wall denunciaba en aquella ocasión que Curiel la había autorizado a pesar de contener algunas afirmaciones condenables. La orden de embargo de los ejemplares ya impresos y distribuidos es un ejemplo de la debilidad de Curiel ante los deseos del ministro, a quien llegó a ofrecer la dimisión. AHN Cons leg 11275/28.

${ }_{25}$ 23/II/1763, Memorial de los libreros; Expediente promovido en virtud de RD 22/III/1763, prescriviendo varias reglas para la Impresión y Venta de Libros, AHN Cons leg 5528/19. RO 3/IX/1764, AHN Cons leg 5528/19.

26 AHN Cons leg 11275/21. 
fines del estudio de las prácticas censorias, es importante la defensa de Curiel, quien hacía notar

que avía evacuado, y hecho cumplir en su impresión, quanto prevenían las leyes, cuya observancia estaba puesta a su cuidado, y no el contenido de los impresos [...]. Si el Juez de Imprentas o el Consejo han de ser responsables de todo quanto se imprime es menester que el Rey lo mande, porque hasta ahora no hay ley que lo prevenga y por esto el Juez de Imprentas y el Consejo se desentiende de las prohibiciones que frequentemente se hacen por el Santo Oficio de la Ynquisición de Libros que autorizados con su licencia se hallan con proposiciones heréticas [....].

También indicaba que para poder ejercer el control posterior a la impresión, y poder recoger los libros no deseables, era mejor la disposición, abolida en 1717, por la que se mandaba entregar a cada miembro del Consejo un ejemplar de cada libro que se pusiera a la venta, aunque Curiel sabía muy bien que en su época esa medida era imposible de aplicar. Claramente intentaba diluir sus responsabilidades involucrando en la tarea de censura al Consejo de Castilla, organismo del que se había desgajado y hecho autónomo el Juez de Imprentas. Para concluir su defensa, de manera no demasiado hábil desde luego, solicitaba que el rey declarara si el Juez de Imprentas debía «reconocer por sí» las peticiones de licencia de impresión, y como eso también era imposible materialmente, terminaba sugiriendo que se siguieran las pragmáticas de 1502 y de 1625 , y que los censores, dado que eran retribuidos, fueran a ser responsables de sus opiniones, no el Juez de Imprentas ${ }^{27}$. Lo que parece quedar claro es que el Juzgado de Imprentas con su estructura y dotación no podía abarcar todo lo que salía a la luz en papel impreso. Atrás quedaba el tono de seguridad del Juez cuando establecía el marco de acción de los censores, y aquí se explica la idea de nombrar a los cuarenta censores; se trataba de diluir responsabilidades o más bien de sacudirse de encima unas atribuciones que ahora Curiel veía eran exageradamente exigentes.

Para perfeccionar el conjunto de medidas de censura, en 1757 Curiel remitía al Subdelegado de Santiago de Compostela la Carta de 23 de marzo tras la orden precedente de examinar "Cartillas para enseñar niños» en donde indicaba que

«La impresión de romance o xácara o cosa semejante de poca importancia» se podía solicitar en papel corriente,

previniendo al impresor que qualquier licencia de estas las deve conserbar en su poder por si en algún tiempo se encontrase algo mudado añadido o quitado, pero quando los impresos fuesen de más volumen como sermones, historias, Discursos, y otros semejantes deven presentarse a V.S. por el escribano en papel se-

27 Pragmáticas 1502 y NR I, VII, 23 de 1625 y NR I, VII, 33. Defensa Curiel, a raíz de la Reprensión 23/II/1756. AHN Cons leg 11275/21.

Hispania, LXIV/2, núm. 217 (2004) 571-600 
llado; y así de estos papeles como de los antezedentes se le deven entregar a V.S. dos exemplares uno que ha de quedarse en su poder y otro que me ha de remitir ${ }^{28}$.

De ese modo centralizaba en manos del Juez de Imprentas más competencias en el campo de la censura gubernativa, siguiendo la política del Consejo de Castilla. De hecho en 1763 salió una Orden del Consejo "para que se remitan a el Juez de Imprentas todas las Lizencias que se dieren en el Consejo para imprimir» a raíz de la petición de licencia presentada por Juan José López de Sedano para imprimir su obra Tabel, tragedia sacada de la Sacra Escriptura. "Se proveió el Decreto siguiente: Madrid veinte y tres de Agosto de mil setezientos sesenta y tres. Remítese al Señor don Juan Curiel, para que tome, providencia, y lo mismo las demás ynstancias de esta clase» ${ }^{29}$. Es decir que se ampliaban las competencias de Curiel, excepto en lo que se refiere a la difusión de textos que para el gobierno representaban la encarnación de sus ideales ilustrados. Así se puede explicar el caso aparentemente contradictorio de la queja de la Sociedad Económica de Sevilla ante el rey porque para imprimir anualmente sus Memorias - tarea impuesta por sus estatutos - encontraba muchos inconvenientes ya que el Subdelegado local sólo podía autorizar la publicación de papeles breves. Al tener que recurrir a la licencia del Juez de Imprentas en Madrid los trámites se alargaban y las dificultades eran tan numerosas como engorrosas; por ello solicitaban al rey que facultara al Subdelegado para emitir las licencias de impresión de ese tipo de trabajos, siempre por supuesto "precediéndolas censuras regulares». Carlos III no podía no estar de acuerdo y Grimaldi se encargaba de transmitir a Curiel la Real Orden que lo despojaba de una fracción de su autoridad ${ }^{30}$. Pero esto ocurría en nombre del superior interés de la sociedad tal y como lo interpretaban los ministros ilustrados, en el momento de difundir las artes y ciencias útiles para el progreso de la nación. En cambio, si se trataba de hacer circular propaganda crítica para con las actuaciones del gobierno, o que pudiera entenderse como amenazadora para la paz social, la actuación del Consejo y del Juez de Imprentas era unívoca. Esto se pone de manifiesto, si fuera necesario, en el año crítico de 1766, el del Motín de Esquilache, con el Bando prohibiendo a todos los súbditos

componer, expender ni retener en su poder Pasquines, Sátiras, Versos, Manifiestos, ni otros Papeles sediciosos, e injuriosos a Personas Públicas o a qualquier Particular

según el Auto Acordado de 14/IV/1766. En él se denunciaba que «algunas Personas ociosas y de perniciosas intenciones», aprovechando la generosidad del rey que había otorgado un indulto «desde el día Veinte y tres hasta el vein-

\footnotetext{
28 AHN Cons leg 50691.

29 AHN Cons leg 50685.

30 RO 18/VIII/1765, AHN Cons leg 50693.
} 
te y seis de Marzo pasado", se dedicaban a componer y difundir impresos subversivos. El grado de preocupación del gobierno ante el Motín queda de manifiesto por la radicalidad de la prohibición: no sólo difundir papeles perniciosos, sino incluso componerlos. Se designaban como competentes en la investigación y castigo de los transgresores a los Alcaldes de Casa y Corte, lo que da también la idea de que para el gobierno los disturbios de marzo habían sido un hecho principalmente madrileño ${ }^{31}$. Con la Real Cédula de 18 de septiembre del mismo año se extendía el control sobre la difusión de críticas al prohibir a los eclesiásticos murmurar contra el gobierno. Las jerarquías religiosas estaban encargadas de aplicar esa orden, pero la Cédula se dirigía a la justicia civil, que a partir de ese momento se presentaba como poder por encima de la organización eclesiástica, postura típica del regalismo de Carlos III ${ }^{32}$, y era que los fomentadores de desórdenes intentaban hacer palanca en la insatisfacción popular inventando pretextos para atacar al gobierno.

De tal manera que en el Extracto de la Causa Criminal [...] sobre Motín de Madrid $^{33}$ se denunciaba

[...] que al año de haver sucedido [el motín de Esquilache] faltó muy poco para haver otro en Madrid, que sin duda hubiera producido peores efectos que el antecedente siendo igualmente ellos [los jesuitas] los causantes, porque especie de que a los hombres ordinarios que en esta Corte se conozen con el nombre de $\mathrm{Ma}$ jos se les havían de cortar las patillas que se dejan sin afeitar a los lados de la cara, y a las mugeres de la misma clase quitarlas los Moños, agujas, y redecillas. Con efecto se iba disponiendo insensiblemente otra borrasca como la pasada y la huviera havido a no estar a la frente de todo un Conde de Aranda [...].

La política di Curiel había consistido en asegurar dentro de lo posible todo el control sobre la letra impresa, y por eso a raíz del asunto del Piscator Complu-

31 AHN Cons lib 1483 nn. 36 e 37. «Notons la date à laquelle les sphères dirigeantes se penchent sur le problème: à la fin des années 1760 , donc en plein prurit réformateur, mais aussi au terme d'une décennie qui s'est vue profondément marquée par le motín de Esquilache (1766), avec pour conséquence la reprise en mains systématique des esprits, les temps forts de cette répression ayant été l'expulsión des jésuites, la mise au pas de l'Inquisition, le lancement de la réforme universitaire». Esta autora llama a la censura «autre branche de police». DOMERGUE, Censure... cit. p. 51. Sobre el Motín véase también CORONAS GONZÁLEZ, S.M.: «El motín de 1766 y la constitución del estado", Anuario de bistoria del derecho español, I, 1997.

32 AHN Cons lib 1483/54. Según Domergue, en tan sólo cinco años, de 1766 a 1771, el gobierno reformador consiguió dotarse de todos los instrumentos necesarios para controlar ideológicamente a la sociedad «Secularización...» cit. Ejemplos de la política religiosa, CARo LÓpEZ, C.: «Propietarios y distraídos», Hispania Sacra 95, 1995, pp. 217-246; ID. «Las asociaciones religiosas madrileñas», Anales del Instituto de Estudios Madrileños XL, 2000, pp. 147-175.

33 BNM mss 11024 , ff. $6 \mathrm{v} .-7 \mathrm{v}$. La solución policial fue la detención de una vendedora de naranjas llamada La Rubia así que no parece que se tratara de una gran conspiración. Sin embargo, cabe la posibilidad de que todo el clima de tensión fuera una táctica de Aranda, presidente del Consejo, para imponer su línea política. Se trataría de un caso de manipulación de los temores del Poder jugando con los resortes de la delación, la censura y la represión de las ideas.

Hispania, LXIV/2, núm. 217 (2004) 571-600 
tense el Juez de Imprentas había propuesto la creación de un cuerpo de censores a sueldo. De hecho, según el Juez de Imprentas,

Quando yo entré a servir esta comisión hallé la práctica de que el Autor de la obra proponía el sugeto, a cuia censura se avía de remitir, y así se egecutaba de cajón, me creí poderoso a enmendar este abuso, y empezé a remitir las censuras especialmente en obras grandes a los más condecorados sugetos, y literatos de esta Corte, pero en vano, porque casi todos se me escusaban por sus mayores ocupaciones, me vi precisado a permitir que el interesado propusiese tres sugetos conocidos y authorizados entre quienes se eligía uno [...] Hoy a la vista del justo castigo de los dos Aprobantes del Piscator Complutense, dudo mucho que aya quien quiera meterse sin utilidad en este riesgo, y avremos de incidir en la antigua práctica más perjudicial que todo.

En la primera mitad del siglo XVIII fueron Jueces de Imprentas, en 1737, Juan Joseph de Mutiloa, nombrado el 27 de febrero para las licencias y las reimpresiones y el Señor De La Encomienda se encargaba de la Tasa; en agosto de 1743 De La Encomienda seguía en la Tasa, y Don Joseph de Bustamante era responsable de las licencias y reimpresiones hasta su muerte en diciembre de 1748 cuando Don Juan Ignacio De La Encina concedía licencias y reimpresiones. En agosto de 1750 De La Encina también se hacía cargo de la Tasa, hasta el 2 de febrero de 1752 en que Don Juan Curiel era nombrado Juez Privativo con jurisdicción sobre todos los aspectos de obras de imprenta. Le sucedería, al ser destituido en febrero de 1769, Don Manuel María de Nava. En 1789 estaba en activo Felipe Ribero ${ }^{34}$.

Desde el primero, según el instrumento de su nombramiento, quedó claro que la jurisdicción de este magistrado se extendería sobre cualquier otro poder civil anteriormente competente. Los avatares de la legislación sobre censura gubernativa pondrán en claro más adelante la voluntad de aplicar su jurisdicción a todo el reino, por una parte, y sus constantes conflictos de autoridad con los poderes locales y con el tribunal del Santo Oficio.

En el asunto de la aplicación de la censura gubernativa no podía no aparecer la defensa y extensión de las regalías de la Corona y esto no podía ocurrir sin que se verificasen choques con las autoridades religiosas. Por ejemplo en el caso de la Junta de Comercio contra don Teodomiro Caro de Briones Subdelegado de Imprentas en Valencia, porque la Junta quería imprimir «ordenanzas, Zédulas y demás papeles que sea nezesario Expedir por el tribunal de la Yntendencia, que no es de menos prerrogatibas que el de la Audiencia, la Ynquisición, el Tribunal Eclesiástico, la Ciudad y la Universidad». Se acusaba al magistrado de abuso de poder en contra de lo establecido con RD 12/XII/1749 e «Instrucción 1754 en

34 Los nombres de los sucesivos Jueces de Imprentas se pueden encontrar en las series del AHN Cons legs. 50627 - 50678, AHN Cons legs 50627 - 50678 y 50686 . También véase GUINARD, op. cit. p. 25. 
que se previene que con las respectivas licencias de los tribunales en que pendan los asuntos se puedan imprimir sin otro requisito los papeles que traten de ellos». El rey reprobaba la acción del Subdelegado y se reiteraban las facultades de la Junta; pero lo más indicativo es que la Junta de Comercio reivindicaba su posición al mismo nivel que las otras instituciones estatales laicas - la Universidad, el Concejo, la Audiencia, y también que los grandes poderes religiosos tradicionales: la Inquisición, el Tribunal eclesiástico ${ }^{35}$.

Para unificar la labor de censura en 1769 una Real Orden mandaba que cesaran en sus funciones los Subdelegados particulares de Imprentas y que en sus lugares entraran los Presidentes de las Reales Chancillerías, los Regentes de las Audiencias y los Corregidores «en quanto subdelegados natos del Consejo», a raíz del Informe del fiscal del Consejo de 22 de mayo ${ }^{36}$. Se mantenía la actitud de defensa de las regalías porque a esas mismas autoridades se encomendaba que no permitieran la difusión de bulas o documentos papales que no hubieran recibido previamente el Pase Regio. En el mismo año se prohibía la impresión de estampas satíricas contra los Jesuitas con Real Cédula 3/X/1769 a causa de la difusión y denuncia en Barcelona de una estampa contra San Ignacio «dirigidas todas a aumentar el fanatismo y a fascinar los Pueblos, abusando de los textos de la Escritura Santa» y "Titulando odio y persecución a lo que ha sido justa y necesaria providencia»; es decir, que se prohibía ese papel porque criticaba las decisiones del gobierno sobre expulsión de la Compañía. La Real Cédula se dirigía a las justicias civiles recién encargadas de la censura ${ }^{37}$ : revistiéndolas por tanto de atribuciones de policía. En 1773 otra Real Cédula de 20 de abril reiteraba el exclusivo derecho de la Corona de conceder licencias de impresión de obras escritas, lo que tocaba algunos privilegios eclesiásticos en la concesión de licencias de libros de devoción ${ }^{38}$. La Real Cédula se originó por la publicación de un libro de teología que contaba con la licencia favorable del obispo de Barcelona y del Regente de la Audiencia, pero según el contexto de las Leyes Reales, era privativo de la Regalía y Jueces Reales el permitir y dar expresa licencia para que se pudiesen imprimir cualesquiera libros y papeles. El fiscal del Consejo interpretaba el Concilio de Trento en el sentido de que había concedido al juez eclesiástico "la mera censura» de los tratados teológicos pero no la facultad de aprobar su publicación, con una reiteración más de la vigençia

35 Decisión del rey asesorado por el Consejo de Hacienda en Sala de Justicia, 17/VIII/1766. Juan de Peñuelas a Curiel, AHN Cons leg 50693.

36 8/VI/1769, AHN Cons lib 1357 f. 221 y BNM Mss 13303.

37 AHN Cons lib 1357 f. 320 . Por otra parte, con Pragmática de 2 de mayo de 1767 se había dado orden al Juez de Imprentas y a sus subdelegados que se inhibieran en la concesión de licencias de obras «concernientes a la expulsión de los Jesuitas de los Rs. Dominios» reservando esa materia a la competencia del Consejo. Si cualquier religioso hubiera querido comentar dicha medida, y publicar sus conclusiones, debería dirigirse para conseguir la licencia a la Primera Secretaría de Estado, según el artículo XVII de la misma. Aranda a Curiel, 30/IV/1767, AHN Cons leg 50694.

38 Completaba la NR I, VIII, 24 caps. 2-4. AHN Cons lib 1361 f. 509.

Hispania, LXIV/2, núm. 217 (2004) 571-600 
de las regalías de la Corona mientras intentaba someter a los jueces eclesiásticos al parecer del funcionario gubernativo. En 1777 se emanaba un Decreto del Consejo de 15 de julio para que

Los libros sagrados, y demás Obras nuevas Theológicas que traten de doctrina de la Yglesia, y se presentasen en el Consejo para su impresión, se remitan al Juez Eclesiástico, para que examinados por sí, o por Personas de su satisfacción, y aprovados con su licencia por lo que a él toca, se traigan al Consejo al fin de acordar o negar la licencia para la impresión, y de esta providencia se pase copia certificada a la escribanía de Cámara de Gobierno de Castilla para que se tenga presente en los casos que ocurran 39 .

Y en 1779 estallaba el caso del Sermón Panegýrico en el que los fiscales del Consejo acusaban al Vicario General, a quien habían encargado la censura de la obra, de no respetar la Real Cédula de 20 de abril de 1763 luego incluida en otra Real Cédula de 1 de febrero de 1778 y según la cual ciertas impresiones precisaban de la autorización del Consejo si tocaban asuntos de religión. El Consejo había pedido al vicario

su informe, y no la Zensura del sugeto que elige para que examine la obra, porque le es facultativo adoptar, o separarse de su dictamen manifestando el propio, y que estima por más conforme y oportuno.

El sugeto era el ordinario eclesiástico, que se había puesto de la parte del vicario, como era natural, pero había errado de medio a medio, porque

No es peculiar del Ecclesiástico el punto de regalías, aunque esté obligado a defenderlas; será suficiente para suscitar questiones, que quedaron fenezidas por la citada Real Cédula de $1^{\circ}$ de febrero de 1778 conservando a cada jurisdicción su authoridad ${ }^{40}$.

La medida de destitución de los subdelegados no tuvo todos los efectos deseados. Pocos años más tarde se abría el Expediente del Arzobispo de Santiago sobre la prohibición de dos edictos episcopales que trataban de abusos en su diócesis. El Consejo pedía explicaciones al entonces Juez de Imprentas, Nava, y éste contestaba que

Desde la providencia de que los Jueces subdelegados para Ympresiones del Reino los nombrase el Consejo, se han creído todos libertados, e independientes de este Juzgado en Madrid y absolutos en sus Departamentos de suerte que así como el Consejo, si no es por algún particular recurso, ignora el curso de las Ym-

39 Decreto del Consejo 15/VII/1777, AHN Cons leg 50692.

40 22/IX/1779. «Recójase» el libro, orden de 22/X/1779. AHN Cons leg 5544/102. 
presiones que se hacen fuera de esta Corte, yo tampoco sé lo que pasa en estos Juzgados ${ }^{41}$.

Es decir, que acusaba al Consejo de haber descentralizado demasiado las tareas censorias. Ahora se notan varias posturas en los organismos del gobierno, todos dedicados a la misma actividad pero con recelos a veces fuertes de unos para con otros. El Consejo prefería saltarse la autoridad del Juez de Imprentas apoyándose en los funcionarios reales, y el Juez de Imprentas se quejaba de que si no estaba en su mano el nombrar a los subdelegados de su confianza no se le podían achacar las faltas de vigilancia en asuntos de censura, actitud que recuerda la de Curiel en su defensa. La centralización de poderes en manos del Consejo seguía verificándose con nuevas disposiciones legales, «en virtud de lo que está prebenido a los subdelegados de Ymprentas del reyno por Carta Acordada 4/III/1774 en punto a que no concedan licencia para la impresión de ningún papel o libro sin dar quenta al Consejo». El resultado era que el corregidor de Murcia - previamente encargado de las tareas de censura previaremitía al Consejo de Castilla dos manuscritos de conclusiones teológicas solicitando la licencia de impresión que él no podía conceder ${ }^{42}$. En este contexto se enmarca también el caso de la «Orden General» por la que no se podían hacer impresiones sin licencia de las autoridades y de la que el regente de la Audiencia de Aragón, don Baltasar de Aperregui, a la sazón y desde lo dispuesto en 1769 Subdelegado de Imprentas informaba a don Manuel de Nava y Carreño - Juez de Imprentas- de que

$\mathrm{Ha}$ suscitado los recursos de la Universidad Literaria de esta Ciudad, del Hospital General de la misma y aun de otros cuerpos distinguidos como son las Reales oficinas, los Fiscales de S.M. y aun la misma Real Audiencia que como cada uno tiene su respectivas facultades para poder Ymprimir los papeles, que dicen les pertenecen, y Yo no se lo niego, pretenden que los Ympresores los Ympriman sin tener el Ymprímase del Subdelegado de Ymprentas. Sin la firma de éste temen los Ympresores estampar los que aquéllos les dan, porque la orden general no esceptúa, y por consiguiente se vulnera, y sobre este asunto me ha parecido Representar a V.S.I. Con los supuestos y fundamentos que se siguen.

De hecho el Subdelegado al recibir una petición de licencia la pasaba a un censor, la censuraba él mismo o la sometía al Vicario General «por lo perteneciente a las buenas costumbres, y también al Fiscal de S.M. para lo tocante a las Regalías». Los papeles de la Universidad y del Hospital General «no necesitan de mi censura» y bastaba que el subdelegado viera la petición para «mandar que se impriman». Ahora, decía el magistrado de Zaragoza,

$41 \quad 16 / \mathrm{V} / 1774$, AHN Cons leg 50687.

${ }_{42} 1 / \mathrm{IV} / 1775$, AHN Cons leg 5537/93.

Hispania, LXIV/2, núm. 217 (2004) 571-600 
Que sin esta circunstancia lo executen los Ympresores, que sólo reconocen por su Superior, y por su Juez, al que lo es de las Ymprentas, no me cave en la Caveza. Porque si es como lo pretenden dichos Cuerpos, los Ympresores tendrán dos Jueces, sobre una misma Ymprenta, el de estos Agraciados, para lo que les está concedido, y el de Ymprentas para lo demás, que no dimana de aquellas comunidades.

Era, una vez más, la voluntad del magistrado delegado por conseguir una parcela, no más amplia pero sí más clara, de su jurisdicción. Y declaraba aún que había pedido seis ejemplares de los papeles impresos porque los necesitaba para la censura y también

porque el honor de esta judicatura, de alguna escepción, obsequio y atención, y más recayendo sobre el empleo de Regente de la Real Audiencia que aun en todo se le reputa con distinción y de las Gacetas (privilegio concedido al Hospital) se dan seis, con que no es exceso lo que ha mandado.

Es decir, que pretendía poner su magistratura al mismo nivel de otras instituciones ciudadanas que gozaban de privilegios formales superiores a los suyos ${ }^{43}$.

En el mismo año, poco después, presentaba petición de que se le permitiera conceder la licencia "para que yo pueda permitir el que se imprima aquí», a la sazón "otra obrilla intitulada Las seis primeras bedades del mundo». Lo más interesante es que ahora el censor se presentaba como benefactor de la imprenta local, pues si pedía al Consejo que se le reconociera esa facultad, no era para acrecentar su jurisdicción, sino porque «A no ser por la Universidad, Sto. Hospital, Sociedad, y algún otro cuerpo esceptuado, se hubieran del todo arruynado las pocas Ymprentas que hay en esta Ciudad [Zaragoza] y no lo tengo por conveniente ${ }^{44}$.

Se puede afirmar que, dentro de su severidad formal, la política de censura del Consejo de Castilla fue en realidad errática, no en el sentido de que cambiara sus objetivos, que consistían siempre en la vigilancia de las obras de imprenta, sino en los modos de conseguirlos. Las decisiones gubernativas oscilaban constantemente entre la descentralización, encargando de la censura a los organismos delegados en las provincias o ciudades, y la desconfianza en estos mismos magistrados con la consiguiente voluntad de centralizar todas las facultades en la Corte. Así se da el Decreto del Consejo de 16 de septiembre de 1777 por el que la licencia y corrección de los impresos correspondería a la «Escribanía de Cámara [del Consejo de Castilla, Sala de Gobierno] a quien tocare» como ya estaba establecido para las estampas de la Corte, mientras que en provincias y en las ciudades los organismos delegados tenían el mero encargo de vigilar que los impresos hubieran recibido la licencia de Madrid $^{45}$.

\footnotetext{
43 23/I/1781, AHN Cons leg 50683.

44 21/IV/1781, AHN Cons leg 50683.

45 AHN Cons leg 50686.
} 
En 1780 se recordaba otra disposición legal mencionada más arriba a propósito del control de los autores «Mediante haverse advertido que se presentan varias obras con nombres supuestos, o en Anagrama, y para evitar los perjuicios que de este abuso se pueden seguir, las Escribanías de Gobierno del Consejo no admitan en lo sucesivo instancia ni pedimento alguno en que se pida licencia para la impresión de qualquiera libro, sin que además de la firma del Procurador tenga también la del editor, o verdadero Autor de la Obra que se intenta imprimir, o que se presente poder suficiente para ello» ${ }^{46}$.

Los dos campos fundamentales de la política censoria gubernativa a partir del último cuarto del Setecientos fueron la importación de libros extranjeros y la vigilancia de la prensa periódica. Hasta el siglo XVIII en España no hay referencias específicas a una ley de censura para periódicos, y lo único que se exigía era que tuvieran licencia previa del Consejo de Castilla ${ }^{47}$. Es muy interesante ver como se desarrollaron los avatares de la censura en este campo, porque cuando aparecieron en el siglo XVIII el Mercurio y la Gaceta de Madrid la secretaría de Estado comprendió la importancia de la prensa periódica e intentó agregar a la Corona esos dos títulos, como ha explicado Rumeu de Armas. En cambio, para la prensa no oficial, el órgano competente seguía siendo el Consejo. Esto fue así hasta la Real Orden de 19 de marzo de 1785, con la que se encargaba al Juez de Imprentas la vigilancia en esa materia ${ }^{48}$. Una vez más se trataba de un conflicto de competencias entre varios organismos del gobierno, con ocasionales roces también con la Inquisición. Ésta había intervenido en el asunto de

Papeles anónimos vajo de diversos títulos [...] por ser muy perjudiciales a nuestra sagrada religión, a las buenas costumbres al estado y a las supremas potestades Eccla. Y Real» [...]. «Pero no ha podido el Santo Oficio practicar las mismas caritativas diligencias con el Autor del Papel intitulado El Censor, porque Don Manuel de Lardizábal Uribe, Fiscal de la R. Sala de Alcaldes de Casa, y Corte, se ha excusado repetidamente a declarar su Nombre, y Apellido, expresando que en el asunto del Censor había procedido de comisión Real, por lo que no contestaría a pregunta alguna mientras no se le exibiese orden de V.M. para ello.

Se nota claramente el enfrentamiento entre poderes y la posición regalista del fiscal Lardizábal, defendiendo la jurisdicción estatal ante la Inquisición, que se había dirigido a Floridablanca para interesar al rey en el asunto. La decisión consistió en pasar el expediente al Consejo de Castilla ${ }^{49}$ pero no consta cuál fue su final. Lo que si es evidente es que el minucioso régimen al que se debían someter

46 Decreto del Consejo 17/I/1780, AHN Cons leg 50691.

47 Sobre la historia de la censura de periódicos, véase GómeZ-REINo, op. cit. pp. 46 ss. Auto Felipe IV 13/VI/1627 = NoR VIII, 16, 9, ratificado por Auto del Consejo de Castilla de 27/XI/1716 $=$ NoR VIII, 16, 13 y Auto Felipe V 4/X/1728 = NoR VIII, 16, 14.

48 RUMEU De ARMAS, op. cit. pp. 90 ss. Véase también GuINARD, op. cit. pp. 25 ss.

49 AHN Cons leg 11278/19. 
las publicaciones periódicas era a todas luces ineficaz. La Real Orden de 19 de mayo de 1785 encargaba al Juez de Imprentas la concesión de licencias para papeles de hasta cuatro o seis pliegos, reservando al Consejo el control de los impresos de mayor extensión ${ }^{50}$, pero como esas medidas no alcanzaban el objetivo deseado, y ante la gravedad de los acontecimientos políticos, en 1791 una Real Resolución prohibía todos los periódicos excepto el Diario de Madrid ${ }^{51}$.

En este caso se trataba de prohibición, pero unos años antes e había dado ya una medida restrictiva para con la libertad de impresión de diarios a propósito de la polémica levantada por la reforma de los teatros que se estaba debatiendo por entonces. En 1788 fue nombrado Juez de Imprentas Felipe Rivero en sustitución de Velasco y Campomanes le encargaba explícitamente que denegara toda licencia de impresión a los periódicos que publicaran sátiras o ataques personales por hechos relativos a la vida teatral. Además de ser una medida de censura gubernativa, era también la demostración del cariz reaccionario de las posiciones políticas de Campomanes entre los reinados de Carlos III y Carlos IV ${ }^{52}$.

La resolución de 1791 no pasaba de ser una demostración de autoritarismo por una parte y de debilidad por otra, al reconocer que los mecanismos de censura tan concienzudamente trabados para controlar ideológicamente la libertad de expresión no alcanzaban sus fines. En los periódicos, se reconocía, "hay muchas especies perjudiciales» y por eso mismo se eliminaban físicamente. El único papel autorizados quedaba

el Diario de Madrid de pérdidas y hallazgos ciñéndose a los hechos, y sin que en él se puedan poner versos ni otras especies políticas de qualquiera clase que sean.

Y sin embargo tampoco se obedecía esa orden, o mejor dicho la censura no conseguía filtrar todos los temas que se publicaban en este periódico, dado que en 1799 aparecía un Discurso sobre el origen de la legislación y gobierno de los pueblos que motivó que el rey diera orden — nuevamente- de que sólo se imprimiesen "las noticias correspondientes a compras y ventas y otras cosas particulares» a la vez que quedaban excluidas terminantemente composiciones poéticas de cualquier tipo, y no sólo «aquella poesía que dixese relación del Gobierno» como se defendían los redactores del periódico ${ }^{53}$.

so Expediente formado en virtud de Real Orden 19/V/1785. «Reservando al Consejo lo perteneciente a Libros formales, y obras de mayor extensión y otros puntos». AHN Cons leg 5550/67. Providencia repetida con RR 27/VIII/1792, AHN Cons leg 50691.

51 RO $19 / \mathrm{V} / 1785=$ NoR VIII, 17,4 y RR 2/X/1788 = NoR VIII,17,3; RR 24/II/1791 = NoR VIII, 17,5. Orden al Juez de Imprentas firmada por Campomanes. AHN Cons leg 1911/46. También GÓmeZ-REINO, op. cit. p. 47.

52 Historia y crítica de la literatura española dirigida por F. Rico, tomo IV-1, "Ilustración y Neoclasicismo», ed. Gies-Sebold, Barcelona 1992, pp. 75-76.

5311 y 23/XII/1799, AHN Cons leg 5563/61. 
A partir de la Revolución francesa, como es sabido, las tareas de censura se volvieron más febriles y las disposiciones legales sobre imprentas y sobre importación de libros, que hasta entonces habían corrido caminos paralelos, se juntaron en normas unificadas que se referían a los dos aspectos. Se publicaron las Reglas que deberán observar... para presentar peticiones de licencia de impresión al Juez de Imprentas según lo establecido por el Consejo: $1^{\circ}$, la petición siempre debería estar firmada; $2^{\circ}$ había que presentar la obra al censor nombrado por el Juez de Imprentas; $3^{\circ}$ «no se pongan expresiones torpes ni lúbricas, ni tampoco sátiras de ninguna especie»; $4^{\circ}$ era obligatorio indicar el autor de los originales en el caso de las traducciones; $5^{\circ}$ tras la impresión, se debía entregar al Juez de Imprentas un ejemplar para cotejarlo con el original censurado; $6^{\circ}$ «finalmente, los Censores no permitirán que en libros ni papeles se trate de asuntos resueltos por S.M. o sus Ministros y tribunales sin consulta o permiso de S.M. o de los mismos Tribunales y ministros respectivos, ni tampoco de los que están pendientes formalmente: pues de lo contrario serán responsables el Autor, y Censores ${ }^{54}$. Desde el 19 de septiembre de 1789 quedaba prohibida en las aduanas la entrada en España de papeles sobre los acontecimientos contemporáneos de Francia ${ }^{55}$ por orden de Campomanes. La disposición legal no indicaba sin embargo obras en concreto; se trataba de crear un cordón sanitario en torno a las noticias de más allá de los Pirineos. Un título concreto en cambio fue el Almanaque de París traducido al español y sometido a la censura de la Sociedad Económica de Madrid. La resolución del Consejo fue tajante:

Escribanos de Cámara y de Gobierno no admitan recurso o instancia en que se solicite licencia para imprimir Papel, Libro o folleto que trate directa o indirectamente de asunto favorable o adverso perteneciente al Reyno de Francia ${ }^{56}$

Habrá que notar que lo que se prohibía no era la circulación de textos favorables a la Revolución, sino de cualquier texto, favorable o contrario. En 1790 Campomanes transmitía a Velarde, gobernador de la Sala de Alcaldes, las provisiones dictadas para prevenir que circularan por España noticias de la Revolución francesa, haciéndole recuerdo de la de la RO de 1789. Había que extremar las precauciones ante las malas artes de los sediciosos que se valían de todos los medios para propagar sus doctrinas; en Cádiz, avisaba Campomanes, se había detenido a un francés

con el chaleco guarnecido con cinquenta y seis quadritos en cuyo centro se figura un Caballo a carrera tendida con un mote o epígrafe a la parte superior, que dice Liberté,

\footnotetext{
54 AHN Cons leg 5556/2.

ss AHN, Cons lib 1327 f. 697.

s6 Es la Resolución del Consejo para que no se introduzcan ni impriman en el Reyno Libros que traten de asuntos concernientes al estado actual de Francia de 13/III/1795, AHN Cons leg 50691.

Hispania, LXIV/2, núm. 217 (2004) 571-600
} 
así que ahora no se vigilaban sólo los libros sino también las prendas de vestir. Lo que puede parecer una extravagancia de la mentalidad absolutista en realidad era un asunto de estado que Lerena había comunicado a Campomanes por la vía reservada de Hacienda en seis de agosto, y éste a la Sala Alcaldes al día siguiente ${ }^{57}$. A partir de los años noventa, además, se agravó la situación a causa de la propaganda revolucionaria procedente de Francia, y ante el aumentado peligro crecían también los recelos de la auténtica eficacia de las instituciones vigentes. Varias voces se alzaron presentando al Consejo o al rey sus propuestas de endurecimiento y/o reforma de las leyes y los organismos de censura gubernativa, especialmente en lo que se refería a la importación y al control de los libros extranjeros, como se verá más abajo; por el momento cumple dejar constancia de la propuesta de creación de un magistrado nuevo, el Promotor Fiscal pergeñado por Felipe de Ribero en carta a Foridablanca ${ }^{58}$ :

Ymporta sin duda crear un centinela con el nombre de Promotor Fiscal que denuncie semejantes escritos y los persiga así respecto a los que descubra su diligencia como los que el Gobierno o personas particulares remitan a sus manos, para ocurrir en lo posible al gravísimo daño de que se propaguen en nro. Reyno los perniciosos escritos que con maligna fecundidad salen diariamente de los países vecinos y otros remotos y librarnos de la combustión en que ellos se abrasan [...] Está V.E. [Floridablanca] persuadido (con razón) a que no son los libros de gran tamaño ni las obras de muchos volúmenes, los enemigos temibles que oy más nos ofenden; su precio, el tiempo y ocio que pide su comprehensión y lectura los hace accesibles a muy pocos y esos son gente por lo común que sabe preservarse del error [...]. El mal que más conviene atajar es el que causan las piezas llamadas fugitivas: los folletos de pocas ojas, parto por lo regular de espíritus fogosos, desenfrenados sin Religión principios ni pudor [...]. Esto se vende barato, se lee luego, le compran todos. Baja a los menestrales y Pueblo; se insinúa insensiblemente en los espíritus,

según la presentación. Es decir, que deseaba se fundara una nueva magistratura dedicada exclusivamente al control de los papeles revolucionarios porque con toda evidencia no le parecería que el Consejo y el Juez de Imprentas estuvieran actuando de manera eficaz. Para calificar las obras se debería recurrir a seis censores además de los ya existentes, que probablemente estarían cargadísimos de trabajo,

y que pueden hallarse entre los Canónigos de S. Ysidro, Curas de Madrid, los Yndividuos de las Academias Médica, de la Lengua y de la Historia, el Oratorio del Salbador, Padres de S. Felipe Neri, Capilla Real, Biblioteca y conventos de la Corte,

57 Reales órdenes probiviendo en España papeles, relaciones y estampas relativas a las ocurrencias de aquella corte y sus turbulencias, 1790. AHN, Cons lib 1380 f. 976.

58 30/XII/1790, AHN Cons leg 11278/94. 
lo que no era ciertamente una novedad pues los censores procedían generalmente de esas instituciones. En cuanto a su salario, «Hai la fortuna de que las necesidades de los Ecclesiásticos Seculares y Regulares se satisfacen a menor costa» así que encima el recurso a los religiosos sería un buen negocio para el gobierno, porque bastarían 100 ducados para los censores y 150 para el Promotor Fiscal. Estas apreciaciones no pasarían de pintorescas si no fuera por la práctica que deseaban imponer: cualquier papel denunciado debería ipso facto quedar confiscado preventivamente; su distribución estaría detenida hasta la censura favorable del Promotor Fiscal, y su prohibición quedaría asegurada en el caso

de abundar el escrito en errores, doctrinas peligrosas, systemas turbatibos de la paz, y tranquilidad del estado, o eversivos de su constitución política,

lo que tampoco representaba una novedad, más allá del hecho de dejar sentado que se trataba de velar por la estabilidad del Estado y el gobierno, y para conseguir ese fin se procedería criminalmente contra los autores. A diferencia de los planes de actuación de la censura gubernativa, como los había plasmado Curiel casi cuarenta años antes, en cambio, entre los objetivos de esta magistratura no estaba el de velar por la ortodoxia religiosa o la defensa de la fe. La propuesta de nombramientos indica, para el cargo de Promotor Fiscal, una terna de nombres formada por don Manuel Torres doctor y catedrático de la Universidad de Oviedo y Abogado de aquel Foro; D. Ramón de Cabrera y D. Nicolás de Cáceres Abogado del Colegio de la Corte. Para los censores: D. Tomás Sánchez de la Biblioteca y ambas Academias; el abad de Montserrat, Segismundo Beltrán; Joseph Francisco Vegas y Quintano cura de la Almudena; Juan Gámez médico de la Cámara y de la Real Academia Médica; Padre Antonio Torres del Oratorio S. Salvador; Padre Vicente Chiribella de S. Felipe Neri; Francisco Marina canónigo de S. Isidro; Miguel Ochoa González capellán de honor, es decir, una vez más la misma preponderancia de individuos religiosos sobre los laicos. Lo más importante de este proyecto es que representaba la quiebra de los valores de la Ilustración, al expresar con todas letras su ataque frontal a lo que en otros tiempos se había considerado como el vehículo de difusión de las Luces: los libros. Pero además de esa postura claramente reaccionaria, hay un reconocimiento claro de la naturaleza de clase del conflicto que se estaba desarrollando, porque no eran los libros en sí lo peligroso, sino cuando éstos se volvían asequibles al público. «Los libros de gran tamaño ni las obras de muchos volúmenes», decía Ribero, no representaban amenazas para el statu quo a causa de «su precio, el tiempo y ocio que pide su comprehensión y lectura». Lo que había que temer, en cambio, eran «las piezas llamadas fugitivas: los folletos de pocas hojas", porque, como reconocía abiertamente, "esto se vende barato, se lee luego, le compran todos». Ahí estaba el problema: que todos pudieran tener acceso a la propaganda escrita, no que circulara, si se limitaba a círculos restringidos. 
Hay otra Orden, de 1786, emanada a petición de la Sala de Alcaldes sobre abuso en las sátiras contra ministros de justicia, que abunda en la represión de manifestaciones críticas para con las instancias del Poder. Al igual que para los papeles subversivos, lo central del asunto es que como se refería a representaciones teatrales, la difusión del mensaje era directa. Por otra parte también era más pintoresca, porque indicaba la voluntad de no consentir expresión alguna ofensiva para con los subalternos de Justicia que los pusiera en ridículo,

ni que se permita salgan los cómicos al Teatro con golilla y varas prohiviendo tales representaciones injuriosas, pues para representar un Alguacil podrán hacerlo en trage de militar y vestido negro acaso con mayor propiedads9.

Y en 1791 una Orden Circular prohibía los «papeles sediciosos contrarios a la tranquilidad pública» ${ }^{60}$ confiando en que las estructuras estatales dedicadas a la vigilancia de libros e impresos fueran capaces de acometer una tarea de tal envergadura.

Las licencias de importación de libros extranjeros correspondían desde siempre a la Inquisición, y las leyes de la primera mitad del Setecientos no hacen mención a esta faceta de la censura hasta la Instrucción Curiel que hacía caer esas obras en la ley general, en su punto XV, según opinión de Rumeu de Armas ${ }^{61}$. Este historiador explica que las primeras prohibiciones gubernativas de libros extranjeros durante el siglo XVIII están siempre en relación con hechos políticos concretos: es el caso de las Reales Cédulas de 20 de junio de 1772 sobre la Historia imparcial de los jesuitas franceses y la de 15 de marzo de 1777 con que «se prohibía un libelo sedicioso, impreso en Amsterdam, y cualquier otro papel alusivo a la extinguida Compañía»; la Memoria Católica quedaba prohibida «igualmente», y los Puntos de disciplina eclesiástica también pues atentaban a las regalías de la Corona ${ }^{62}$. Sin embargo esas medidas concretas no fueron las primeras manifestaciones de la voluntad de atajar la circulación por el reino de libros impresos fuera de él, aunque las fronteras sean en algunos casos inesperadas, como en la primera provisión del siglo XVIII, de ocho de agosto de 1757 por la que se prohibía importar libros en romance procedentes del «extranjero y de Navarra» ${ }^{63}$. Se daban instrucciones a los oficiales de aduanas para que vigilaran y se establecía el embargo de las

59 Orden 3/VII/1786. Firmada Campomanes para los Alcaldes y reiterada en 30/VII/1786 y en 9/VIII/1786. AHN Cons lib 1376 ff. 1382 r-v.

60 OC 5/I y RC 10/IX/1791. RuMEU De ARMAS, op. cit. p. 75.

61 RumeU De ARMAS, op. cit. pp. 68 ss. El autor dice que no se conoce la suerte que corrió la decisión sobre ese punto, aunque el reglamento se aprobó con Real Resolución de 27 de julio de 1754 pero sugiere que, dada la importancia del trabajo de Curiel, el punto XV se supeditara a otros aspectos de la censura gubernativa.

62 Rumeu De ARMAS, op. cit. p. 70, nota 2.

63 Hasta la RC 23/X/1783 sobre el modo de importar libros impresos en Navarra, que es una medida de libertad de comercio, pero que mantenía naturalmente las restricciones en lo que se refería a los libros prohibidos. 
obras y las penas para los infractores. El Juez de Imprentas pedía a los Directores Generales de Rentas que «se aplique a los Ministros de las Aduanas la tercera parte del valor de los libros que aprendiesen o comunicasen» sin duda para incentivar su celo investigador. Un año más tarde, desarrollando la orden real, Curiel proponía que, puesto que los fardos de libros eran voluminosos,

si se les [a los oficiales aduaneros] obligase a desvalixar en los Puertos estos bultos para reconozer los libros que incluyen sería un grave perxuicio al Comercio, por que los interesados no tienen en ellos personas intellixentes que asistan a este reconocimiento ni prensas, o tornos para volverlos a empacar (como lo executa el $\mathrm{St}^{\circ}$ oficio de la Ynquisición) que los referidos bultos o empaques se sellen por las costuras en las referidas Aduanas, de suerte que no puedan abrirse, y otorgándose fianza de ponerlos en la Aduana correspondiente a su destino.

Nótese que la propuesta del Juez de Imprentas estaba formulada con el objetivo declarado de hacer más eficaz el reconocimiento de los paquetes de libros que se presentaban a las aduanas, y que se tomaba como ejemplo de funcionamiento los procedimientos usados por el Santo Oficio. El Conde de Valdeparaíso, interlocutor de Curiel, comunicaba la decisión del gobierno, que sin embargo es anodina: "Se ha prevenido a los Directores Generales de Rentas comuniquen orden general a las Aduanas del Reyno para que se logren las intenciones del Rey sobre evitar, sin perjuicio del Comercio, la introducción de obras en Romance ympresas fuera del Reyno» ${ }^{64}$. En 1763 se prohibía la introducción en el reino de cualquier título impreso en el extranjero si se publicaba ya en España, pero esa medida se tomaba para salvaguardar la industria nacional. Mismo fin tenía la Real Cédula 2 de junio de prohibición de importar libros encuadernados, para favorecer a los artesanos españoles ${ }^{65}$.

Para muchos, sin embargo, los mecanismos estatales existentes no eran suficientes para controlar los libros importados, y en la década de los noventa se levantaron voces - como las de Manuel Quevedo Bustamante o Tomás de Sorreguieta - para reclamar el fin de las imprentas o solicitar abiertamente la ayuda del tribunal de la Inquisición. Quevedo Bustamante se centraba en consideraciones negativas sobre la pésima calidad de las imprentas y de ahí razonaba que los buenos autores se arrimaban a las buenas imprentas, y las malas imprimían «vagatelas» o se dedicaban «lo que es peor a imprimir obras prohibidas» en sus «Miserables oficinas». Para completar el silogismo era suficiente concluir con que se solucionaría el problema ... icerrando las imprentas!.

a1 14/I/1758, AHN Cons leg 50694.

65 Además esa Real Orden reconocía los privilegios de las universidades y regulaba los derechos de autor, puntos que no entran en el campo de este estudio. RO 14/XI/1762, RO 20/XI/1763, RC 2/VI/1778 (De carácter económico, no habla de contenido de las obras, sólo de la defensa de los productos de la industria nacional), RC 9/VII/1778 y Carta Circular 28/II/1778 recordando la RC 20/IV/1773, NoR VIII, XVI, 26, RO 14/VI/1778. AHN Cons lib 1366, CoronAs GONZÁleZ, Libro de las leyes cit. pp. 2195-96.

Hispania, LXIV/2, núm. 217 (2004) 571-600 
Habría que reducir los establecimientos de Madrid de los actuales 26 a 13 salvando la Imprenta Real, y las de la Viuda de Ybarra, Sancha, Marín, Cano, Espinosa, Barco, Aznar, Ortega, Doblado, Ruiz, Villalpando y de la Compañía de Impresores. Con éstas "hay las suficientes para imprimir quanto ocurra». Por la misma razón no se debería permitir que hubiera más de «una en cada Capital [de provincia]» y el mismo mal se diagnosticaba de la «multitud de librerías». Además ningún impresor debería poder tener tienda y también era perjudicial que cualquiera pudiera tener "puesto de libros", porque

Con presentar al público un miserable estante o Cajón con quatro libros viejos e inútiles son los que fomentan los hurtos de libros de los hijos de familia.

Luego había que prohibir todos los puestos callejeros excepto los de las gradas de San Felipe porque ésos pertenecían a mercaderes más responsables y serios. Por si fuera poco, en esa visión apocalíptica, se denunciaba el incumplimiento de las leyes vigentes en las mismas imprentas, "añadiendo, corrigiendo y haciendo quanto se les antoja a los Autores sin preceder licencia». Quevedo Bustamante pensaba que, para controlar los textos impresos, sería conveniente que los impresores presentaran ante la Comisión de Imprentas los originales para cotejarlos con las impresiones que salían de sus talleres - pero eso ya estaba regulado por leyes anteriores. La segunda parte de la ofensiva contra los libros se dirigía, como era inevitable, a los importados. "Apenas se puede concebir el gran descuido que hay acerca de la Yntroducción de libros así Ympresos en el Reyno como estrangeros», se lamentaba, pero no se refería a los que pasaban de contrabando, sino a los que entraban legalmente por culpa de la incompetencia de los aduaneros; en su caso concreto, estaba muy indignado por la libertad con que se introducía en España las Ruinas de Palmira de Volney. Quevedo Bustamente proponía la creación de una Junta presidida por el Juez de Imprentas

$$
\begin{aligned}
& \text { y a la que acompañase un Yndividuo nombrado por la Inquisición, cuyo objeto fuese } \\
& \text { examinar todos los libros extrangeros y nacionales que se introdujesen en el reyno }
\end{aligned}
$$

y que tendría facultad para autorizar la venta de ese tipo de textos aunque los mecanismos de control y represión de libros importados ya existieran antes de que Quevedo Bustamante propusiera sus arbitrios. La novedad importante consistía en la propuesta de integrar a la Inquisición en los organismos estatales ${ }^{66}$. El otro paladín del Santo Oficio, Tomás de Sorreguieta, deprecaba en 1798 la funesta epidemia de libros que libremente entraban y se difundían por España propagando el libertinaje y la irreligión; decía que el Santo Oficio no era suficiente para detener, con su sola vigilancia, todas esas amenazas «porque no es más que parcial semejante pesquisa, y rigurosa condenación». Sólo era

6r Quevedo Bustamante, M.: Observaciones y reglas sobre el Ramo de Ymprentas 1797, AHN Cons leg 11923/6.

Hispania, LXIV/2, núm. 217 (2004) 571-600 
una tarea parcial, y la prueba es que había muchas brechas en la barrera inquisitorial, por las que entraban en oleadas periódicos y gacetas extranjeras. Sorreguieta denunciaba que si la situación había llegado a ese grado de peligro era porque el Estado no había apoyado lo suficiente a la Inquisición; para solucionar ese estado de cosas proponía que se emanara una ley válida para todo el reino y fuertemente restrictiva, plasmada bajo las indicaciones del Tribunal. ${ }^{67}$. Las posturas de los más contrarios a la difusión de libros extranjeros no dependían sin embargo solamente de la coyuntura histórica del momento concreto, sino que reflejaban el malestar de un sector de las capas dirigentes, activo abiertamente desde los años setenta del siglo.

Los proyectos de estos arbitristas no llegaron a tener plasmación en el ordenamiento jurídico de las postrimerías del siglo Dieciocho, pero es evidente que reflejan el interés y la preocupación por la circulación de libros no gratos desde el punto de vista de los intereses del Poder, y por eso no faltaron otras medidas emanadas directamente desde el Consejo o la Corona. Así, la Real Resolución de 1798 y su consiguiente Expediente ${ }^{68}$ por los que se mandaba recoger todos los libros prohibidos que estuvieran en posesión de los libreros. Ezpeleta comunicaba a Bartolomé Muñoz la orden de aplicar la resolución real y entonces el Consejo encargaba a los Alcaldes de Casa y Corte para que hicieran las pesquisas en sus cuarteles, pesquisas de las que se librarían los Estudios de San Isidro y el Seminario de Nobles, no porque estuvieran exentos del cumplimiento de la ley, sino porque esas instituciones recibirían las órdenes directamente del Consejo de Castilla y no de sus subalternos. Al parecer, los libros prohibidos circulaban por la Corte con total impunidad. La censura se estaba convirtiendo cada vez más en un asunto de estado y no ya de mera administración y a raíz del asunto Bonola y el Pájaro en la Liga ${ }^{69}$, se mandaba que

en los permisos de impresiones de obras o papeles, particularmente de la clase religiosa, proceda [el Juez de Imprentas] con la reserva, y circunspección que le es propia, sino que después de bien examinadas las que le parezcan que lo merecen \{la licencia de impresión] las remita antes de acordar su permiso a la $1^{\text {a }}$ Secretaría de Estado acompañada con las Censuras y el juicio que forme de ellas, y de las obras, para que dando cuenta a S.M. de todo, vea si se está en el caso de la impresión.

Así se establecía un nuevo filtro de censura, con el doble efecto de reducir la jurisdicción efectiva del Juez de Imprentas y de fortalecer el absolutismo regio al poner todo el sistema de control ideológico abiertamente bajo la decisión de la Corona.

\footnotetext{
67 De SoRREguIETA, T.: Proyecto importantísimo en orden a la introducción de libros y papeles extrangeros $y$ nacionales, 1798, AHN Estado leg 2937. Véase HERRERO, J.: Los origenes del pensamiento reaccionario español, Madrid 1971, cap. IV, «Los discípulos españoles: Zeballos, Rodríguez, Valcarce» (pp. 91 ss.).

68 Expediente formado en virtud de Real Resolución... 20/I/1798, AHN Cons leg 5562/94.

69 RO 17/I/1799, AHN Cons leg 50691.
}

Hispania, LXIV/2, núm. 217 (2004) 571-600 